\title{
The muscarinic stimulation of phospholipid labeling in hippocampus is independent of its cholinergic input
}

\author{
STEPHEN K. FISHER, CARL A. BOAST * and BERNARD W. AGRANOFF \\ Neuroscience Laboratory, Mental Health Research Institute and Department of Biological Chemistry,
} University of Michigan, Ann Arbor, Mich. 48109 (U.S.A.)

(Accepted January 3rd, 1980)

Key words: phospholipid labeling effect - hippocampus - muscarinic -- cholinergic input

The enhanced incorporation of ${ }^{32} \mathrm{P}_{i}$ into two minor acidic phospholipids, phosphatidate and phosphatidylinositol, is a response characteristic of a number of effectors, including neurotransmitters and hormones, with their receptors on the cell membrane. In the nervous system, this is perhaps best documented in the case of acetylcholine action on brain synaptosomes, slices or on sympathetic ganglia (for review, see ref. 14). This 'phospholipid labeling effect' (PLE) appears to require tissue structural integrity since it is not observed in cell-free preparations. The PLE elicited by muscarinic agonists in nerve ending fractions ${ }^{19}$ might be considered an exception. However, isolated synaptosomes retain considerable internal structure and metabolic viability, and as such may be considered as resealed anucleate neurons. Neurotransmitter receptors have traditionally been considered to be localized on the postsynaptic membrane, and a number of indirect approaches suggest that the neurotransmitter-directed PLE in pineal gland ${ }^{21}$ and superior cervical ganglion ${ }^{11}$ is associated with this site. In the case of synaptosomes, this conclusion is not readily made. For example, the assumption that added ${ }^{32} \mathrm{P}_{\mathrm{i}}$ must first be converted to $\gamma^{32} \mathrm{P}$-ATP before phospholipids can be labeled suggests that intrasynaptosomal oxidative phosphorylation is an obligate step in the synaptosomal PLE (see ref. 19), an argument that would appear to favor a presynaptic localization. Furthermore, postsynaptic membranes are not prominent in the 'light' synaptosomal fraction shown to mediate the PLE in guinea pig brain fractions ${ }^{20}$. The case for a presynaptic site is however by no means conclusive. In a recent study, we concluded that calcium mobilization accompanies the muscarinic PLE (see ref. 5) in synaptosomes. The increase in calcium availability that parallels the PLE is at variance with the probable physiological role of presynaptic muscarinic receptors in cerebral cortex in reducing neurotransmitter release ${ }^{15,22}$. by appearing to limit calcium availability ${ }^{13}$. That is, we would have anticipated that ac-

* Present address: Research Department, Pharmaceuticals Division, CIBA-GEIGY Corporation, 556 Morris Ave., Summit, N.J. 07901, U.S.A. 
tivation of a presynaptic receptor would be mimicked by reducing rather than by increasing calcium flux. The observed calcium effect prompted us to re-examine the inferred localization of the cholinergic receptors responsible for the synaptosomal PLE. In this report, we have experimentally broached this question by examining the role of cholinergic innervation on the acetylcholine (ACh)-induced PLE in synaptosomes derived from the hippocampus. The hippocampus supports a robust PLE and its sole cholinergic input from the septal nuclei can be readily disrupted by the placement of lesions in the fornix. As discussed below, the lesion is expected to cause degeneration of cholinergic presynaptic fibers, but should have little effect on the integrity of postsynaptic structures, and thus provide a means of further localizing the synaptosomal PLE.

Male guinea pigs $(250-350 \mathrm{~g})$ were anesthetized with pentobarbital $(35 \mathrm{mg} / \mathrm{kg})$ and placed in a stereotaxic frame (Kopf Instruments). Bilateral anodal electrolytic lesions of the fornix $(0.5 \mathrm{~mm}$ posterior to bregma, $5.2 \mathrm{~mm}$ below brain surface and 1 $\mathrm{mm}$ lateral to the midline) were effected by passing a current of $8 \mathrm{~mA}$ for $30 \mathrm{sec}$. Eight to ten days after surgery, the guinea pigs were killed by stunning and exsanguination, the overlying cortical structures displaced by means of a blunt spatula, and the hippocampal formation (including subiculum, dentate gyrus and hippocampus proper) from both sides removed. The hippocampal formation (150-240 mg wet weight) was homogenized in $6 \mathrm{ml}$ of $0.32 \mathrm{M}$ sucrose and a nerve ending fraction $\left(\mathrm{P}_{2} \mathrm{~B}\right)$ prepared by conventional methods ${ }^{8}$. Lipid labeling from ${ }^{32} \mathrm{P}_{\mathrm{i}}$ in the absence and presence of $\mathrm{ACh}$ $\left(10^{-4}\right.$ plus $10^{-4} \mathrm{M}$ eserine) was carried out by incubating aliquots of synaptosomes (200-400 $\mu \mathrm{g}$ protein) in a medium containing (final concentrations): $100 \mathrm{mM}$ sodium glycylglycinate buffer ( $\mathrm{pH} 7.4) ; 1 \mathrm{mM}$ sodium pyruvate; $1 \mathrm{mM}$ sodium fumarate; 1 $\mathrm{mM} \mathrm{MgSO}_{4} ; 0.5 \mathrm{mM} \mathrm{CaCl}_{2} ; 0.1 \mathrm{mM} \mathrm{NaH}_{2} \mathrm{PO}_{4}$; and $60-150 \mu \mathrm{Ci}$ of ${ }^{32} \mathrm{P}_{\mathrm{i}}$ (carrier free) in a total vol. of $0.25 \mathrm{ml}$. Incubations were terminated after $45 \mathrm{~min}$ and lipids extracted and quantified essentially as described previously ${ }^{20}$. Choline acetyltransferase (ChAT) was determined by a radiochemical assay ${ }^{6}$. Acetylcholinesterase (AChE) activity was measured spectrophotometrically at $37^{\circ} \mathrm{C}$ by the method of Ellman et al. ${ }^{3}$, with the inclusion of $10^{-5} \mathrm{M}$ tetraisopropylpyrophosphoramide to inhibit pseudocholinesterase activity ${ }^{12}$. The binding of $\left[{ }^{3} \mathrm{H}\right]$-quinuclidinylbenzilate (QNB) was measured by incubating $40-160 \mu \mathrm{g}$ of protein for $60 \mathrm{~min}$ at $25^{\circ} \mathrm{C}$ in the presence of $1 \mathrm{nM}$ QNB $(29.4$ $\mathrm{Ci} / \mathrm{mmol})^{25}$. Reactions were terminated by rapid vacuum filtration of assay components through glass fiber filters (Whatman GF/B). Specific binding is defined as total binding minus binding in the presence of $10^{-6} \mathrm{M}$ atropine. Glutamate decarboxylase (GAD) activity in synaptosomes (70-250 $\mu \mathrm{g}$ protein) was determined by measuring ${ }^{14} \mathrm{CO}_{2}$ evolution from sodium $\mathrm{L}-\left[1-{ }^{14} \mathrm{C}\right]$ glutamate. Each incubation contained (final concentrations): $2 \mathrm{mM}$ sodium L-glutamate $(0.28 \mathrm{mCi} / \mathrm{mmol}) ; 50 \mathrm{mM}$ sodium phosphate buffer (pH 6.8); $1 \mathrm{mM}$ dithiothreitol; $0.2 \mathrm{mM}$ pyridoxal-5'-phosphate; 10 $\mathrm{mg} / \mathrm{ml} \mathrm{BSA} ; 1 \mathrm{mM}$ sodium arsenite and $0.5 \%(\mathrm{v} / \mathrm{v})$ Triton X-100 in a total vol. of 0.1 $\mathrm{ml}$. Reactions were terminated after $120 \mathrm{~min}$ and the ${ }^{14} \mathrm{CO}_{2}$ evolved at $37{ }^{\circ} \mathrm{C}$ measured as described previously ${ }^{4}$. Protein was determined by the method of Geiger and Bessman ${ }^{7}$. Results are expressed as mean \pm S.E.M. Student's t-tests were used to evaluate differences in means of sets of data. 
In unlesioned control animals, the inclusion of $10^{-4} \mathrm{M}$ ACh stimulated the incorporation of ${ }^{32} \mathrm{P}_{\mathrm{i}}$ into both phosphatidate ( $\mathrm{PhA}$ ) and phosphatidylinositol (PhI) by 86 and $55 \%$ respectively (Table I). Atropine $\left(10^{-5} \mathrm{M}\right)$ completely blocked this stimulation of lipid labeling, while D-tubocurarine $\left(10^{-4} \mathrm{M}\right)$ had no effect. This result is in accordance with our previous observations, and those of others, showing that the cholinergic PLE in cerebral cortex ${ }^{19}$, caudate nucleus ${ }^{1}$ and sympathetic ganglia ${ }^{18}$ is muscarinic.

The extent and nature of changes in both basal and stimulated lipid labeling were not significantly affected by interruption of the cholinergic input. Thus, after placement of fornix lesions, synaptosomal fractions from the hippocampus showed mean stimulations of $\mathrm{PhA}$ and $\mathrm{PhI}$ labeling of 76 and $41 \%$ respectively, on addition of ACh (Table I). In marked contrast, the fornix lesions resulted in a large $(72 \%)$ reduction of ChAT, a presynaptic cholinergic marker enzyme ${ }^{6}$, and a $56 \%$ reduction of AChE, an enzyme also considered to be presynaptic in the hippocampus ${ }^{17,24}$. Since several animals showed an almost total loss of ChAT activity, the partial loss following lesions is more likely to reflect an incomplete transection of fiber tracts, rather than the presence of a separate population of cholinergic neurons. The prevalence of muscarinic receptors present in the synaptosomal fraction, as determined by $\left[{ }^{3} \mathrm{H}\right]$ QNB binding, was unchanged following the lesion, which suggests that these synaptosomal muscarinic receptors are not present on cholinergic nerve endings. Although it is possible that a small population of presynaptic muscarinic receptors may exist within the hippocampus ${ }^{16,27}$ it seems unlikely that they contribute significantly to the PLE. GAD activity also remained unchanged after the fornix lesions, indicating that intrinsic GABAergic neurons had not been affected.

\section{TABLE I}

The effect of fornix lesions on the phospholipid labeling effect, marker enzymes and muscarinic receptor binding in synaptosomal fractions from hippocampus

$\triangle \mathrm{PhA}$ and $\triangle \mathrm{PhI}$ refer to per cent stimulation of labeling from ${ }^{32} \mathbf{P}_{1}$, by $\mathrm{ACh}$. Units of measurement were as follows: ChAT, AChE and GAD: nmol/mg protein/min; QNB: pmol bound/mg protein; protein: $\mathrm{mg} / \mathrm{g}$ wet weight. The numbers in parentheses refer to the number of separate experiments. Values for marker enzyme activities and QNB binding were also obtained for whole homogenates from both control and lesioned groups. These results indicated that alterations in the various parameters after fornix lesions closely paralleled those in the nerve ending fraction.

\begin{tabular}{lllll} 
& \multicolumn{1}{c}{ Control } & \multicolumn{3}{c}{ Lesioned } \\
\hline$\Delta$ PhA & $86 \pm 5$ & $(12)$ & $78 \pm 4$ & $(15)$ \\
$\Delta$ PhI & $55 \pm 6$ & $(12)$ & $42 \pm 6$ & $(15)$ \\
ChAT & $1.52 \pm 0.07$ & $(12)$ & $0.42 \pm 0.06$ & $(17)^{*}$ \\
AChE & $71.2 \pm 6.3$ & $(9)$ & $31.3 \pm 4.8$ & $(9)^{*}$ \\
QNB & $0.98 \pm 0.08$ & $(11)$ & $0.94 \pm 0.06$ & $(10)$ \\
GAD & $2.31 \pm 0.15$ & $(8)$ & $2.22 \pm 0.14$ & $(13)$ \\
Protein & $10.3 \pm 0.6$ & $(15)$ & $9.8 \pm 0.2$ & $(17)$
\end{tabular}

* Statistically different from control group, $P<0.001$. All other comparisons were not significant at the $P=0.05$ level. 
The dissociation of the synaptosomal PLE from the septal cholinergic input demonstrates that the muscarinic receptors coupled to stimulated $\mathrm{PhA}$ and $\mathrm{PhI}$ turnover are present on structures that are non-cholinergic in origin. Possible sites of localization of these cholinergic receptors include the dopaminergic, noradrenergic or serotonergic nerve endings shown to be cholinoceptive in other systems ${ }^{2,10,13}$, or on dendrite-derived particles ('dendrosomes') ${ }^{9}$.

While we cannot at present unequivocally identify the membrane locus of the PLE, the most parsimonious interpretation of our results is that in hippocampal synaptosomes, and by inference, in brain synaptosomes in general, the PLE occurs in a structure that is postsynaptic to the physiological site of the ACh release. In this respect, the postsynaptic location of the synaptosomal PLE is in accord with the inferred site of stimulated lipid labeling observed in sympathetic ganglia ${ }^{11}$ and pineal gland ${ }^{21}$.

This work was supported by NIH Grant NS15413. S.K.F. and C.A.B. were supported by NIMH Training Grant MH07417.

1 Canessa De Scarnati, O., Sato, M. and De Robertis, E., Muscarinic receptors and the ACh stimulated phosphatidylinositol effect in the CNS, J. Neurochem., 27 (1976) 1575-1577.

2 De Belleroche, J. and Bradford, H. F., Biochemical evidence for the presence of presynaptic receptors on dopaminergic nerve terminals, Brain Research, 142 (1978) 53-68.

3 Ellman, G. L., Courtney, K. D., Andres, V. and Featherstone, R. M., A new and rapid colorimetric determination of acetylcholinesterase activity, Biochem. Pharmacol, 7 (1961) 88-95.

4 Fisher, S. K. and Davies, W. E., Some properties of guinea pig brain glutamate decarboxylase and its inhibition by the convulsant allyglycine (2-amino-4-pentenoic acid), J. Neurochem., 23 (1974) 427-433.

5 Fisher, S. K. and Agranoff, B. W., Calcium and the muscarinic synaptosomal phospholipid labeling effect, $J$. Neurochem., in press.

6 Fonnum, F. and Walaas, I., The effect of intrahippocampal kainic acid injections and surgical lesions on neurotransmitters in hippocampus and septum, $J$. Neurochem., 31 (1978) 1173-1181.

7 Geiger, P. J. and Bessman, S. P., Protein determination by Lowry's method in the presence of sulphydryl reagents, Analyt. Biochem., 49 (1972) 467-473.

8 Gray, E. G. and Whittaker, V. P., The isolation of nerve endings from brain: an electronmicroscopic study of cell fragments derived by homogenization and centrifugation, $J$. Anat. (Lond.), 96 (1962) 79-88.

9 Hefti, F. and Lichtensteiger, W., Subcellular distribution of dopamine in substantia nigra of rat brain: effects of $\gamma$-butyrolactone and destruction of noradrenergic afferents suggest formation of particles from dendrites, J. Neurochem., 30 (1978) 1217-1230.

10 Hery, F., Bourgoin, S., Hamon, M., Tenaux, J. and Glowinski, J., The role of nicotinic and muscarinic receptors in the control of the release of newly synthesized ${ }^{3} \mathrm{H}-5-\mathrm{HT}$ in rat hypothalamic slices, Naunyn Schmiedeberg's Arch. exp. Path. Pharmak., 296 (1977) 91-97.

11 Hokin, L. E., Effects of acetylcholine on the incorporation of ${ }^{32} \mathrm{P}$ into various phospholipids in slices of normal and denervated superior cervical ganglia of the cat, J. Neurochem., 13 (1966) 179-184.

12 Hoover, D. B., Muth, E. A. and Jacobowitz, D. M., A mapping of the distribution of acetylcholine, choline acetyltransferase and acetylcholinesterase in discrete areas of rat brain, Brain Research, 153 (1978) 295-306.

13 Langer, S. Z., Presynaptic receptors and their role in the regulation of transmitter release, Brit. J. Pharmacol, 60 (1977) 481-497.

14 Michell, R. H., Inositol phospholipids and cell surface receptor function, Biochim. biophys. Acta (Amst.), 415 (1975) 81-147. 
15 Molenaar, P. C. and Polak, R. L., Stimulation by atropine of acetylcholine release and synthesis in cortical slices from rat brain, Brit. J. Pharmacol., 40 (1970) 406-417.

16 Nordström, O. and Bartfai, T., Muscarinic autoreceptors regulate acetylcholine release in synaptosomes from rat hippocampus, Proc. 7th Mtg. Int. Soc. Neurochem., (1979) 507.

17 Olderfeld-Nowak, B., Narkiewicz, O., Bialowas, J., Dabrowska, J., Wieraskzko, A. and Gradowska, M., The influence of septal nuclei lesions on activity of acetylcholinesterase and choline acetyltransferase in the hippocampus of the rat, Acta. neurobiol. Exp., 34 (1974) 583-601.

18 Pickard, M. R., Hawthorne, J. N., Hayashi, E. and Yamada, S., Effects of surugatoxin and other nicotinic and muscarinic antagonists on phosphatidylinositol metabolism in active sympathetic ganglia, Biochem. Pharmacol., 26 (1977) 448-450.

19 Schacht, J. and Agranoff, B. W., Effects of acetylcholine on labeling of phosphatidate and phosphoinositides by [ $\left.{ }^{32} \mathrm{P}\right]$ orthophosphate in nerve ending fractions of the guinea-pig cortex, J. biol. Chem., 247 (1972) 771-777.

20 Schacht, J., Neale, E. A. and Agranoff, B. W., Cholinergic stimulation of phospholipid labeling from ${ }^{32} \mathrm{P}$ orthophosphate in guinea pig cortex synaptosomes in vitro: subsynaptosomal localization, J. Neurochem., 23 (1974) 211-218.

21 Smith, T. L., Eichberg, J. and Hauser, G., Postsynaptic localization of the alpha receptormediated stimulation of phosphatidylinositol turnover in pineal gland, Life Sci., 24 (1979) 2179-2184.

22 Szerb, J. C. and Somogyi, G. T., Depression of acetylcholine release from cortical slices by cholinesterase inhibition and by oxytremorine, Nature (Lond.), 241 (1973) 121-122.

23 Szerb, J. C., Hadhazy, P. and Dudar, J. D., Release of $\left[{ }^{3} \mathrm{H}\right]$ acetylcholine from rat hippocampal slices: effect of septal lesion and of graded concentrations of muscarinic agonists and antagonists, Brain Research, 128 (1977) 285-291.

24 Vijayan, V. K., Distribution of cholinergic neurotransmitter enzymes in the hippocampus and the dentate gyrus of the adult and the developing mouse, Neuroscience, 4 (1979) 121-137.

25 Yamamura, H. I. and Snyder, S., Postsynaptic localization of muscarinic cholinergic receptor binding in rat hippocampus, Brain Research, 78 (1974) 320-326. 